\section{ECONOMICS}

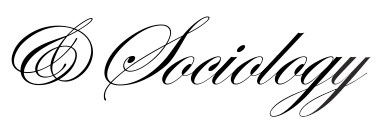

Vasylieva, N., \& James, H. (2021). The effect of urbanization on food security and agricultural sustainability. Economics and Sociology, 14(1), 76-88. doi:10.14254/2071-789X.2021/14-1/5

\title{
THE EFFECT OF URBANIZATION ON FOOD SECURITY AND AGRICULTURAL SUSTAINABILITY
}

\author{
Natalia Vasylieva \\ Dnipro State Agrarian and \\ Economic University, \\ Dnipro, Ukraine \\ E-mail:vasylieva.n.k@@,dsau.dp.ua \\ Harvey James, Jr. \\ University of Missouri, \\ Columbia, MO, USA \\ E-mail: HJames@missouri.edu
}

Received: March, 2020

1st Revision: January, 2021

Accepted: March, 2021

DOI: $10.14254 / 2071-$

789X.2021/14-1/5

\begin{abstract}
Because urbanization is an inevitable process accompanying economic growth, this research specifies impacts of urbanization on food security and agricultural sustainability, with a particular focus on Ukraine. Using methodological fundamentals of econometrics and divisive hierarchical clustering, the analysis depicts country features, world patterns, and notable examples of implementing food security and sustainable agricultural development. Data come from the Food and Agricultural Organization of the United Nations, the World Bank Data, and State Statistics Service of Ukraine. Polynomial regressions show gradual sustainable agricultural development in Ukraine driven by domestic urbanization from 1996 to 2018. The analysis identifies country standing among 186 states distributed into four major world clusters of the pruned binary tree and evaluated through urbanization and securing food availability and affordability. The findings from comparative profiles of selected leading countries determine prospects of Ukrainian urban market size, crop farming and animal husbandry, food production per capita, employment in agriculture, and share in GDP, both within and beyond the EU. Matching at a country level reconciles urbanization with providing food security and economic, environmental, and social components of agricultural sustainability.
\end{abstract}

Keywords: trends of urbanization, world food security, divisive hierarchical clusters, EU profiles of sustainable agriculture, Ukraine.
JEL Classification:C38, C51, O13, O57

\section{Introduction}

Growth of population and urbanization are core driving forces affecting the sustainability of agricultural development and the nature of global food security. Sustainable development is a prime goal of progress according to the Food and Agricultural Organization (FAO) of the United Nations. It declared that "to be sustainable, agriculture must meet the needs of present and future generations for its products and services, while ensuring profitability, environmental health and social and economic equity" (FAO, 2020). McKenzie and Williams (2015, p. 221) stated that "sustainability constitutes the entry point for all agricultural development." Food security is paramount since it provides "a universal human right that is 
realized when all people have physical and economic access at all times to adequate food or the means for its procurement, without discrimination of any kind" (FAO, 2020).

Urbanization is an inevitable trend of economic progress. Globally, total urban population surpassed total rural population in 2008. Urbanization has dual implications for agriculture. Firstly, urbanization correlates with economic growth. Thus, it amplifies purchasing power of food consumers, increases their ability and willingness to pay more for qualitative and diversified agricultural products, expands domestic markets, and incentivizes export/import operations (Stage et al., 2009; Knorr et al., 2018). Small agricultural farmers face significant pressures to consolidate their assets in order to increase the effectiveness of their activities and remain competitive. Secondly, urbanization results in a reduction in viable farmland and accelerates both environmental contamination and ecological degradation (McKenzie and Williams, 2015; Katan et al., 2018). Consequently, agriculture becomes more dependent on intensive technologies, advanced processing, and innovative management practices (Seto and Ramankutty, 2016). This is why it is important to focus on the beneficial and disadvantageous impacts of urbanization on developing agricultural sustainability and mitigating perils of food insecurity.

Exploring the link between urbanization and food security is a pressing issue. Thus, important insights can be obtained by studying the interactions of urbanization and food security in different countries. For this reason, this study focuses on Ukraine, which is one of the largest agricultural countries in Europe. On the one hand, Ukraine belongs to the top world exporters of cereals and oilseeds. On the other hand, domestic animal husbandry cannot maintain food security even at the national level (Vasylieva, 2019). Given the ongoing integration into the global market environment, it is necessary to study the influence of urbanization on sustainable agricultural development and food security in Ukraine.

\section{Literature review}

Numerous studies demonstrate the importance of providing food security. Solving this problem is both urgent and complicated. It is urgent because of the need for agriculture to feed over 9 billion people by 2050 (Grafton et al., 2015). It is complicated because food security is affected by a confluence of economic, political, social, and other factors. For instance, Van Bavel (2013) showed that ignoring optimization of farm inputs and forgoing investments in relevant scientific investigations triggers growth in poverty and famine, increases in pollution and the exhaustion of natural resources, and accelerates a sharp rise in migration pressure. Similarly, Gardner (2013) and Meyers and Kalaitzandonakes (2015) explored the ways to produce at least $50 \%$ more food by 2050 despite an unfavorable climate change, increase in energy costs, and continuing turbulence in international agricultural trade policy. Alfieri (2016) offered actions that could maintain sustainability and ensure global food security by both availability and affordability components. It involved strategic goals to limit agricultural expansion, promote genetic diversity of crops, foster different forms and capacities of farming, balance consumption, food waste and post-harvest losses, arrange elastic and fair trade regimes, and control the rate of urbanization.

Important here is the idea that "no nation has prospered without urbanization and there is no prosperous nation that is not predominantly urban" (Satterthwaite et al., 2010, p. 2810). It is expected that $66 \%$ of the world population would live in cities by 2050 and that the shares of the rural dwellers in Europe, North and Latin America would drop below 20\%. Asia and Africa are expected to be at least $50 \%$ and $20 \%$ of the world concentration in urban areas in coming years. When urbanization advances, different countries raise different concerns about coordinating the goals of food security and sustainable agricultural development with the 
realities of population dynamics and urbanization. For example, Africa demonstrates the highest velocity of urbanization. However, it often takes a form that disrupts benefits of urban economic growth, contributing to social inequality and chronic malnutrition of local people (Arouri et al., 2014). Meanwhile, Chen et al. (2018) and Kundu (2011) undertook comprehensive studies aimed at planning harmonized urban transformations and providing food security with regard to the most populated countries - China and India. It is a tangible challenge, since these states would accumulate about $18 \%$ and $12 \%$ of the world city residents by 2025 .

In order to elaborate the depicted issues with regard to Ukraine, the objective of this study is to examine impacts of urbanization on indicators of sustainable agricultural development and to reveal its prospects based on the important international patterns. To this end, the presented research accomplishes the following three tasks:

- Task 1: examining the domestic influence of urbanization on basic indicators of sustainable agricultural development in Ukraine;

- Task 2: specifying the standing of Ukraine among other countries with regard to food security and unfolding world urbanization;

- Task 3: determining comparative profiles of developing effective agricultural sustainability and food security within and beyond the EU top countries to facilitate Ukrainian adjustments to the realities of the urban world.

\section{Methodological approach}

The methodological approach to complete task 1 was econometrics (Greene, 2007; Studenmund, 2016). Specifically, the study utilized the following $\mathrm{N}$-degree polynomial regressions

$$
\mathrm{Y}=\mathrm{A}_{0}+\sum_{\mathrm{i}=1}^{\mathrm{N}} \mathrm{A}_{\mathrm{i}} \cdot \mathrm{X}^{\mathrm{i}}
$$

where an explainable variable $\mathrm{X}$ denotes the share of urban population, in \%; numerical regression coefficients $A_{i}, i=0, \ldots, N$ are calculated by means of the least squares method; the explained variable $\mathrm{Y}$ refers to the indicators of sustainable agricultural development accessible from State Statistics Service of Ukraine, including

- share of agriculture in Gross Domestic Product (GDP), in \%;

- crop production per capita, in the national currency UAH;

- animal production per capita, in the national currency UAH;

- employment in agriculture, in \%.

To fulfill task 2 , the study compares advancements of urbanization worldwide and in Ukraine, utilizing simple linear regressions such as

$$
\begin{aligned}
& \mathrm{Z}^{\mathrm{W}}(\mathrm{t})=\mathrm{B}_{0}^{\mathrm{W}}+\mathrm{B}_{1}^{\mathrm{W}} \cdot \mathrm{t}, \\
& \mathrm{Z}^{\mathrm{U}}(\mathrm{t})=\mathrm{B}_{0}^{\mathrm{U}}+\mathrm{B}_{1}^{\mathrm{U}} \cdot \mathrm{t},
\end{aligned}
$$

where $\mathrm{t}$ denotes a variable of time; $\mathrm{B}_{0}^{\mathrm{W}}, \mathrm{B}_{1}^{\mathrm{W}}, \mathrm{B}_{0}^{\mathrm{U}}, \mathrm{B}_{1}^{\mathrm{U}}$ are numerical regression coefficients calculated by means of the least squares method; $\mathrm{Z}^{\mathrm{W}}$ and $\mathrm{Z}^{\mathrm{U}}$ designate shares of global and Ukrainian urban population, in \%.

Official statistics confirm higher velocity of the world urbanization than that in Ukraine. Therefore, equations (2) and (3) are used to determine the year of $T$ when $Z^{\mathrm{W}}(\mathrm{T})=\mathrm{Z}^{\mathrm{U}}(\mathrm{T})$, or when global and Ukraine urbanization are equal, which is

$$
\mathrm{T}=\left(\mathrm{B}_{0}^{\mathrm{W}}-\mathrm{B}_{0}^{\mathrm{U}}\right) /\left(\mathrm{B}_{1}^{\mathrm{U}}-\mathrm{B}_{1}^{\mathrm{W}}\right) \text {. }
$$


Furthermore, in order to identify the comparative standing of Ukraine among other countries (Babenko et al., 2017; Kolesnyk et al., 2018), each country was evaluated by indicators of the urbanization level and securing food availability and affordability, namely:

$-\mathrm{C}_{1}$ described its share of urban population, in \%;

$-\mathrm{C}_{2}$ characterized its average value of food production per capita, in Int\$;

- $\mathrm{C}_{3}$ presented its Gross Domestic Product per capita, in Int\$.

The methodological foundation for comparing Ukraine with other countries was the divisive hierarchical clustering (Kaufman and Rousseeuw, 2005). This procedure generates a structure of a binary tree unfolded by three conditional splits relative to the corresponding Ukrainian indicators $\mathrm{C}_{1}^{\mathrm{U}}, \mathrm{C}_{2}^{\mathrm{U}}$, and $\mathrm{C}_{3}^{\mathrm{U}}$. In particular,

- first split was subject to $\mathrm{C}_{1}<\mathrm{C}_{1}^{\mathrm{U}}$ versus $\mathrm{C}_{1} \geq \mathrm{C}_{1}^{\mathrm{U}}$;

- second split was on condition of $\mathrm{C}_{2}<\mathrm{C}_{2}^{\mathrm{U}}$ versus $\mathrm{C}_{2} \geq \mathrm{C}_{2}^{\mathrm{U}}$;

- third split was subject to $\mathrm{C}_{3}<\mathrm{C}_{3}^{\mathrm{U}}$ versus $\mathrm{C}_{3} \geq \mathrm{C}_{3}^{\mathrm{U}}$.

This procedure makes it possible to distribute comparable countries into $2^{3}=8$ clusters marked by signs of their relevant conditions from the first (top) to the third (bottom) split (as shown in Graph 1). In order to capture the world pattern of major connections between urbanization and food security in the allocated countries, the empty clusters or those with minor loading below $1 \%$ were removed or "pruned" in terms of the divisive hierarchical clustering. The remaining clusters were distinguished via their average indicators. In total, this procedure delivered an informative picture of Ukrainian standing among agricultural competitors and consumers in the urbanizing world.

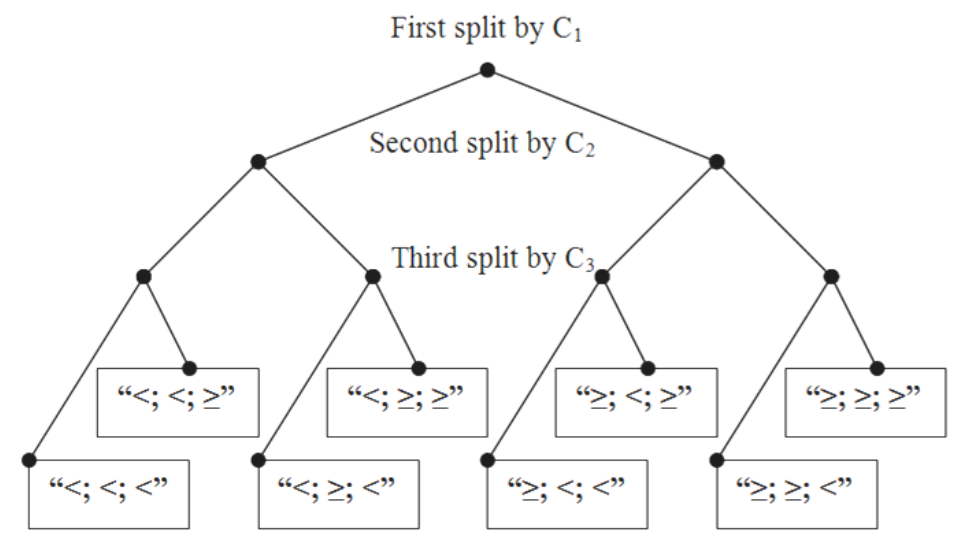

Graph 1. Initial tree of divisive hierarchical clustering

Source: own composition

The methodological approach to address task 3 involved a comparative statistical analysis (Keyfitz and Caswell, 2010; Mitchell, 2011) suitable for assessing deviations of Ukrainian agriculture from the best practices within and beyond the EU. For these purposes we selected 7 appropriate indicators that relate to food security (Headey and Ecker, 2013) and were accessible from statistics of the Food and Agriculture Organization of the United Nations and the World Bank Data. These include:

- share of urban population, in \%;

- share of agriculture in GDP, in \%;

- average food production per capita, in Int\$; 
- arable land per capita, in ha;

- daily animal protein supply per capita, in g;

- share of male employment in agriculture, in \%;

- share of female employment in agriculture, in \%.

The listed composition has the following interpretation. Firstly, the share of agriculture in GDP and average food production per capita display an economic component of sustainability. Secondly, arable land per capita and daily animal protein supply per capita describe an environmental component of sustainability relevant to global ecological challenges caused by agriculture. Finally, shares of male and female employment in agriculture link to its social part.

Ukrainian prospects of sustainable agricultural development were completed as follows. Let $F_{i}^{U}, i=1, \ldots, 7$, be Ukrainian values of the listed indicators. Their deviations $D_{i}, i=1, \ldots, 7$, from the corresponding average top world indicators $F_{i}^{W}, i=1, \ldots, 7$, were calculated by means of the equations:

$$
\begin{gathered}
D_{i}=F_{i}^{W}-F_{i}^{U}, i=1,2,6,7, \\
D_{i}=\left(F_{i}^{W}-F_{i}^{U}\right) / F_{i}^{U} \cdot 100, i=3,4,5 .
\end{gathered}
$$

Importantly, equation (5), applies to the shares of urban population, agriculture in GDP as well as male and female employments in agriculture, evaluated the considered deviations in percentage point. In contrast, equation (6), utilized for the indicators of an average food production per capita, arable land, and daily animal protein supply, assessed the examined deviations in percent.

\section{Conducting research and results}

The described research methodology entailed the relevant empirical outcomes presented in this section.

\subsection{Agricultural sustainability influenced by urbanization in Ukraine}

To synchronize calculations with launching the national Ukrainian currency (UAH) in 1996, the research time frame covered the period 1996 to 2018 . The analysis relevant to task 1 relied on time-series samples derived from State Statistics Service of Ukraine (2020) in compatible prices in UAH for 1996 to 2018. Balancing between the sample size and demand for regression goodness-of-fit, this research considered only first- and second-degree polynomials (1). The computed regressions are exhibited in the Graph 2. The calculated Rsquared coefficients verified their sufficient goodness-of-fit, whereas urbanization dynamics explained, respectively, $70 \%, 90 \%, 90 \%$, and $70 \%$ of changes in the analyzed Ukrainian indicators.

Firstly, the calculations identified the ongoing upward trend concerning the share of agriculture in Ukrainian GDP after some decline around the level of $68.5 \%$ of urban population (see the Graph 2,a). This promising signal means that national agriculture captures advantages of urbanization and is a stable sector of the Ukrainian economy in difficult times (Khalatur et al., 2018).

Secondly, the regression of crop production showed that an increase of urban population in Ukraine by 1 percentage point resulted in an average increase in crop production by 2073.5 UAH or $\$ 76.2$ per capita (see the Graph 2, b). This confirms a sustained Ukrainian commitment to food security in cereals and oilseeds segments of the agrifood sector (Vasylieva, 2019). 


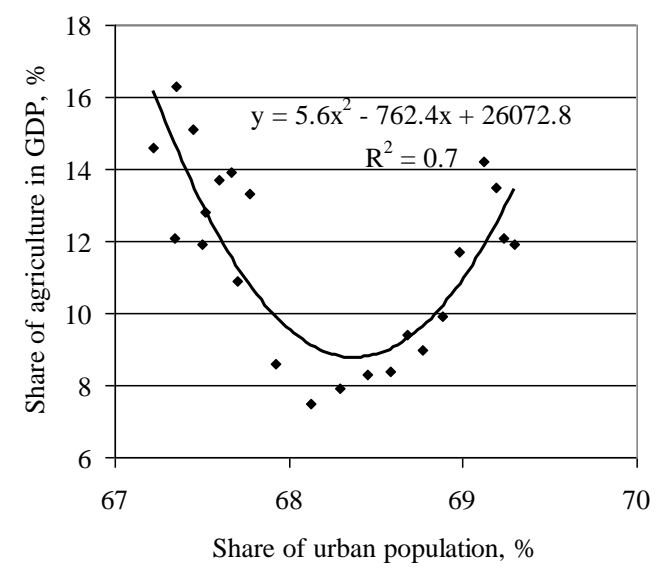

a

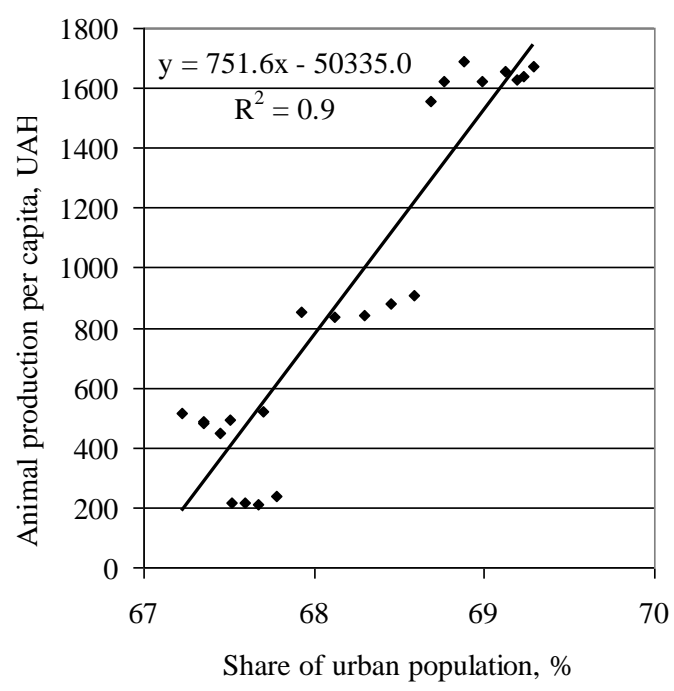

c

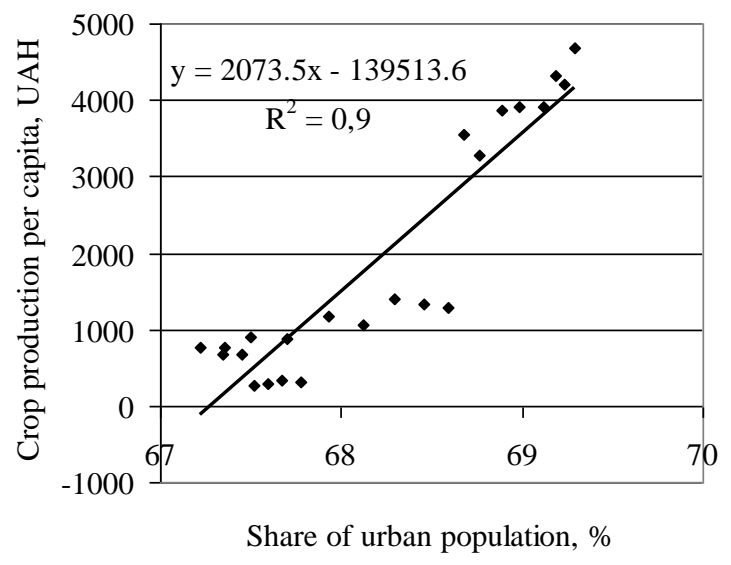

b

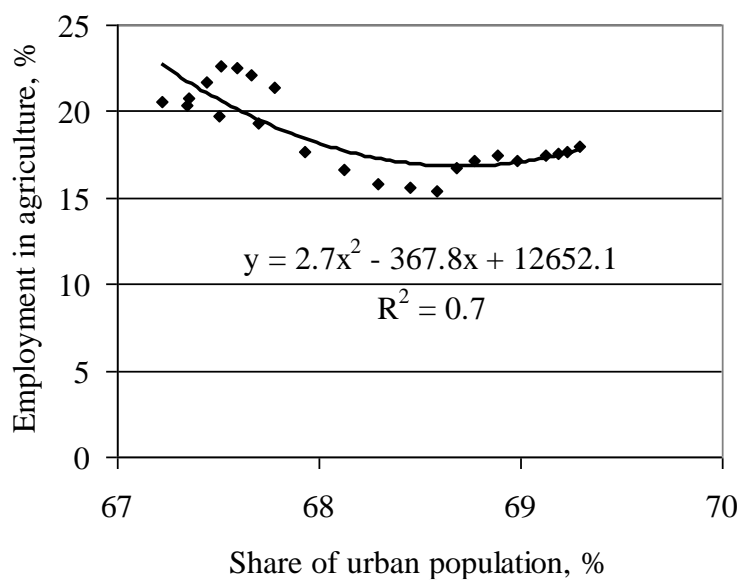

d

Graph 2. Econometric relation between urbanization in Ukraine and indicators of agricultural sustainability

Source: own calculation

Thirdly, the regression of animal production showed that an increase of urban population in Ukraine by 1 percentage point resulted in an average growth in animal production by 751.6 UAH or $\$ 27.6$ per capita (see the Graph 2, c). This lags behind the previous indicator of crop husbandry and suggestsan unfulfilled social obligation of Ukrainian agriculture to the domestic consumers with the unsaturated demands for meat and milk (Vasylieva, 2019). It also emphasizes that in light of sustainable agricultural development, crop and animal husbandry could be better balanced in terms of specialization and diversification (Czyzewski \& SmedzikAmbrozy, 2015).

Finally, calculations showed stable employment of $18 \%$ in Ukrainian agriculture during the last 5 years (see the Graph 2, d). In positive terms, it demonstrates that the national agricultural sector remains an important social niche for Ukrainian labor force. In negative terms, it is consistent with the assumptions of Karamushka et al. (2018) that many Ukrainian farmers use outdated technologies since the progressive urbanization directs agriculture 
"towards more capital- and energy-intensive and less labor-intensive farming" (Satterthwaite et al., 2010, p. 2815).

\subsection{World pattern of urbanization and food security}

The initial calculations relating to task 2 were originated from time-series data on urbanization observed worldwide and in Ukraine for 1996 to 2018 (The World Bank Data, 2020). The resulting regressions are presented in the Graph 3. They show an average annual rise in urban population by 0.47 percentage point across the globe and by 0.1 percentage point in Ukraine. Based on equation (4), Ukrainian and the world indicators would reach the equal levels of $73 \%$ by 2056 .

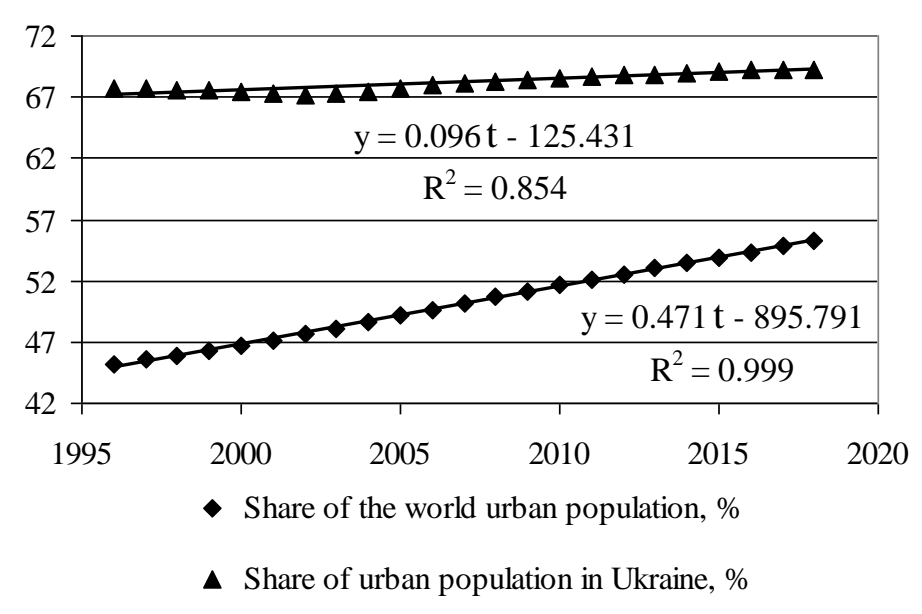

Graph 3. Regressions of urbanization dynamics worldwide and in Ukraine Source: own calculation

The divisive hierarchical clustering relating to task 2 relied on a cross-sectional sample of 186 countries with the accessible indicators for 2018 from FAO (2020). The analyzed countries encompassed $99.1 \%$ of the world population, excluding populous states of Syria, Somalia, and Venezuela. Given the Ukrainian indicators of $\mathrm{C}_{1}^{\mathrm{U}}, \mathrm{C}_{2}^{\mathrm{U}}$, and $\mathrm{C}_{3}^{\mathrm{U}}$, the countries a distributed into four major clusters as marked in the Graph 1.

In particular, the cluster " $<;<;<$ " accumulated low-income countries, which had GDP per capita less than in Ukraine. These 70 countries with the total population of $42 \%$ were Afghanistan, Angola, Bangladesh, Belize, Benin, Bolivia, Burkina Faso, Burundi, Cabo Verde, Cambodia, Cameroon, the Central African Republic, Chad, the Comoros, Congo, Cote d'Ivoire, the Democratic Republic of Congo, Eritrea, Ethiopia, Gambia, Ghana, Guatemala, Guinea, Guinea-Bissau, Guyana, Haiti, Honduras, India, Kenya, Kiribati, Kyrgyzstan, the Lao PDR, Lesotho, Liberia, Madagascar, Malawi, Mali, Mauritania, Micronesia, Moldova, Morocco, Mozambique, Myanmar, Nepal, Nicaragua, Niger, Nigeria, North Korea, Pakistan, Papua New Guinea, Rwanda, Samoa, Senegal, Sierra Leone, the Solomon Islands, South Sudan, Sudan, Tajikistan, Tanzania, Timor-Leste, Togo, Tonga, Tuvalu, Uganda, Uzbekistan, Vanuatu, Viet Nam, Yemen, Zambia and Zimbabwe. These countries are most exposed to unsustainable development and food insecurity (Mikalauskiene et al., 2018).

The cluster " $<;<; \geq$ " merged mostly middle-income countries, which had larger GDP per capita but lower urbanization than those in Ukraine. These 48 countries with the total 
population of $29.3 \%$ included Albania, Antigua and Barbuda, Armenia, Austria, Azerbaijan, Barbados, Bhutan, Bosnia and Herzegovina, Botswana, China (mainland), Croatia, Cyprus, Ecuador, Egypt, Estonia, Eswatini, Fiji, Georgia, Grenada, Indonesia, Jamaica, Kazakhstan, Latvia, the Maldives, Mauritius, Mongolia, Montenegro, Namibia, North Macedonia, Panama, the Philippines, Poland, Portugal, Romania, Saint Kitts and Nevis, Saint Lucia, Saint Vincent and the Grenadines, Serbia, the Seychelles, Slovakia, Slovenia, South Africa, Sri Lanka, Suriname, Thailand, Trinidad and Tobago, Tunisia and Turkmenistan.

The cluster " $\geq ;<; \geq$ " contained generally high-income urbanized countries surpassing Ukraine. These 50 countries with the total population of $16.6 \%$ were Algeria, The Bahamas, Bahrain, Belarus, Belgium, Brunei Darussalam, Bulgaria, Chile, Colombia, Cuba, Czechia, Dominica, the Dominican Republic, Equatorial Guinea, Finland, Gabon, Germany, Hong Kong, Hungary, Iceland, Iran, Iraq, Israel, Italy, Japan, Jordan, Kuwait, Lebanon, Libya, Luxembourg, Macao, Malaysia, Malta, Mexico, Nauru, Norway, Oman, Peru, Puerto Rico, Qatar, Russia, Saudi Arabia, Singapore, South Korea, Sweden, Switzerland, Taiwan, Turkey, the United Arab Emirates and the United Kingdom.

All countries in the described clusters had their food productions per capita below the Ukrainian indicator. However, the cluster " $\geq$; $\geq$; $\geq$ " aggregated urbanized countries with higher indicators of economic and agricultural development than Ukrainian ones. These 14 countries with the total population of $10.4 \%$ were Argentina, Australia, Brazil, Canada, Costa Rica, Denmark, France, Greece, Lithuania, the Netherlands, New Zealand, Spain, Uruguay, and the USA.

The divisive hierarchical clustering detected three country-outliers. Specifically, Ireland and Paraguay with the total population of $0.15 \%$ appeared to have particularly high welfare and sustainable agricultural development accompanied by relatively low urbanization of $63.2 \%$ and $61.6 \%$ compared to Ukrainian indicator of $69.4 \%$. In addition, El Salvador, with a total population of $0.08 \%$ and domestic urban share of $72 \%$, appeared to have poor food security that was below Ukrainian indicators of $\mathrm{C}_{2}^{\mathrm{U}}$, and $\mathrm{C}_{3}^{\mathrm{U}}$. Neglecting the portrayed minor world pattern connected to the issue in question, the research findings to task 2 resulted in the pruned tree of the divisive hierarchical clustering as shown in the Graph 4.

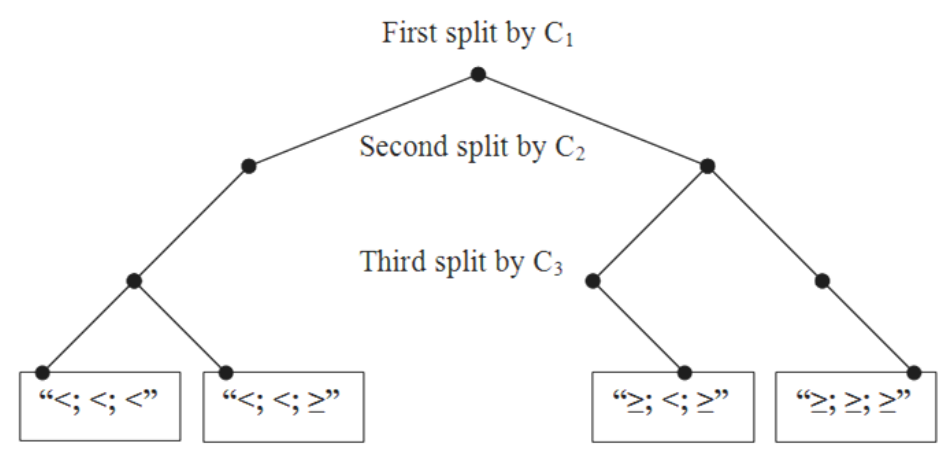

Graph 4. Pruned tree of divisive hierarchical clustering

Source: own composition

The average indicators of the clusters as well as similar Ukrainian characteristics are collected in the Table 1, which shows the general upward trends in changes in GDP and food productions per capita driven by an increase in urbanization. Unfortunately, present economic circumstances in Ukraine complicate improvements of agricultural sustainability, because low GDP per capita positioned Ukraine at the bottom of the cluster " $<;<; \geq$ ". However, Ukrainian 
farming has capacities to compete with the countries from the cluster " $\geq ; \geq ; \geq$ ". That is, it should be ready to address further urban growth and stronger involvement into the global food security system.

Table 1. Average indicators of the world major clusters and Ukraine

\begin{tabular}{lccc}
\hline Cluster & $\begin{array}{c}\text { Share of urban population, } \\
\%\end{array}$ & $\begin{array}{c}\text { Food production per } \\
\text { capita, Int } \$\end{array}$ & GDP per capita, Int\$ \\
\hline$"<;<;<"$ & 38.8 & 124 & 3538 \\
\hline$"<;<; \geq "$ & 52.5 & 179 & 18224.4 \\
\hline$" \geq ;<; \geq$ & 83.9 & 160 & 39584.9 \\
\hline$" \geq ; \geq ; \geq "$ & 84.2 & 608 & 34213.2 \\
\hline Ukraine & 69.4 & 398 & 7906.5 \\
\hline
\end{tabular}

Source: own calculation

\subsection{Top profiles of agricultural sustainability within and beyond the $E U$}

Calculations relevant to task 3 were based on cross-sectional samples retrieved from FAO (2020) and the World Bank Data (2020). Given the cluster " $\geq$; $\geq$; $\geq$ " and notable outliers such as Ireland and Paraguay, the comparative statistical analysis dealt with two groups of top countries:

- those within the EU, such as Denmark, France, Greece, Ireland, Lithuania, the Netherlands, and Spain;

- those beyond the EU, such as Argentina, Australia, Brazil, Canada, Costa Rica, New Zealand, Paraguay, Uruguay, and the USA.

Their quantitative descriptions concerning sustainable agricultural development, food security and urbanization are reported in the Table 2 . The prospects of agricultural sustainability in Ukraine quantified by means of equations (5) and (6) are presented in the Graph 5.

Table 2. Average indicators of the top countries and Ukraine

\begin{tabular}{|c|c|c|c|c|c|c|c|}
\hline Countries & 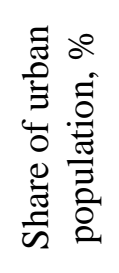 & 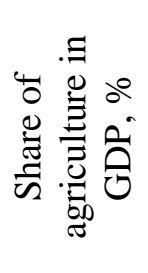 & 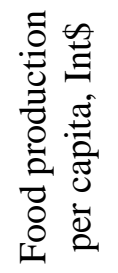 & 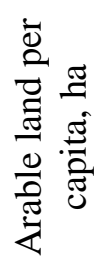 & 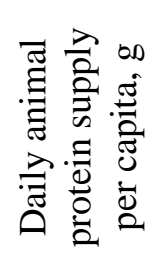 & 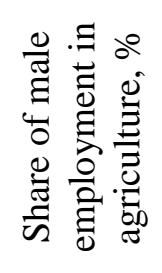 & 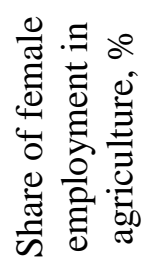 \\
\hline Ukraine & 69.4 & 11.9 & 398 & 0.73 & 42 & 17 & 13 \\
\hline $\begin{array}{l}\text { World Top } \\
\text { within the EU }\end{array}$ & 78.9 & 2.1 & 517 & 0.29 & 67 & 7 & 3 \\
\hline $\begin{array}{l}\text { World Top } \\
\text { beyond the EU }\end{array}$ & 83.4 & 4.8 & 680 & 0.72 & 55 & 9 & 4 \\
\hline
\end{tabular}

Source: own calculation

Firstly, as shown in the Graph 5, the urban domestic market in Ukraine is expected to increase by 10 to 14 percentage point according to experiences of the analyzed top countries.

Secondly, the relatively large share of agriculture in GDP in Ukraine means that other national industries are not as effective as agriculture. Indeed, according to the top countries beyond the EU agricultural share in GDP expects to drop from $11.9 \%$ to $4.8 \%$ (see the Table 2), so that other Ukrainian industries might have provided Int $\$ 19601.5$ instead of Int $\$ 7906.5$ of Ukrainian GDP per capita. 
Thirdly, food production within and beyond the EU exceeds that of Ukraine by $30 \%$ and $71 \%$, respectively. Despite difficult times in Ukraine, there are many options for enhancing agricultural productivity through implementing innovations and effective management (Karamushka et al., 2018; Velychko and Velychko, 2017). Such approaches are the cornerstone of agricultural prosperity in the examined top countries (Godfray and Garnett, 2014). Therefore, their advanced practices are worth a separate exploration, adaptation and implementation in Ukrainian agriculture.

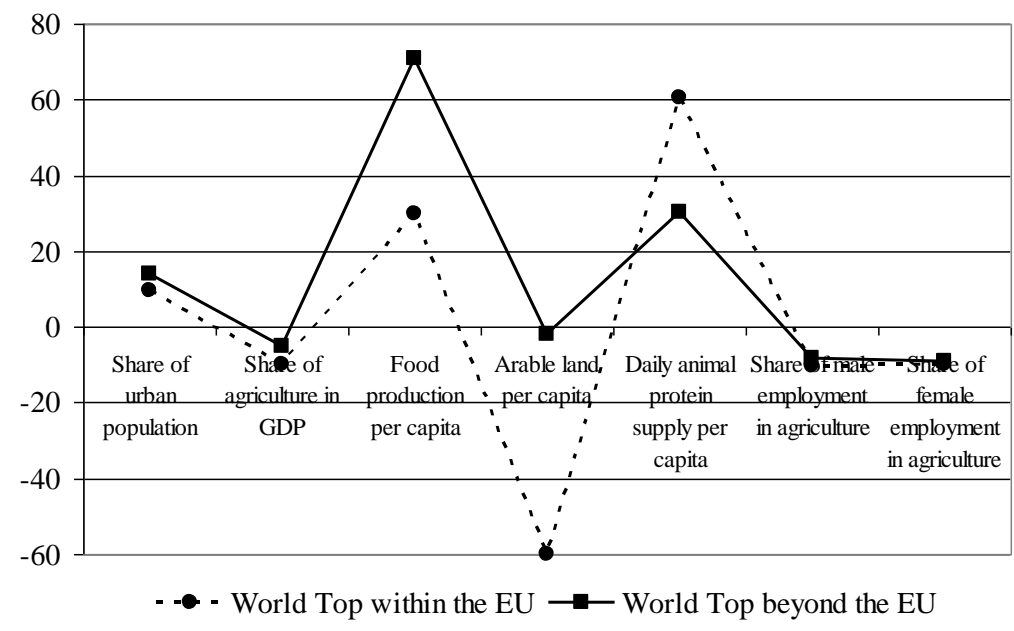

Graph 5. Comparative profiles of agricultural sustainability

Source: own calculation

Fourthly, the indicator of arable land per capita showed equal capacities of crop farming in Ukraine and the top countries beyond the EU. In comparison with the top EU countries, Ukraine had an advantage of $60 \%$. Unfortunately, the restricted market turnover eliminates farmland benefits of the national agriculture (Koroteyev et al., 2017; Skrypnyk et al., 2018).

Fifthly, the indicator of animal protein per capita is very important for providing healthy nutrition (Khan et al., 2017). Thus, Ukrainian agriculture should focus on amplifying its animal husbandry by 30 to $61 \%$.

Sixthly, the comparative profiles showed that Ukrainian agriculture involves more men and women than those ones in the top countries. Larger deviations were found for female employment by 9 percentage point beyond and 10 percentage point within the EU. Overall, Ukraine follows the common trend on the dominant male employment in agriculture which surpasses the female engagement by 4 percentage point (Doss et al., 2018). Meanwhile, statistics convinces that the further urbanization will agree "with fewer people working in agriculture and more working in transport, wholesaling, retailing, food processing and vending" (Satterthwaite et al., 2010, p. 2815).

\section{Conclusion}

This study showed that the upward trend in Ukrainian urbanization is consistent with the ongoing positive changes in sustainable agricultural development. Global urbanization facilitates positive tendencies in both economic growth and food security. Specifically, increments by 45 percentage point in the shares of urban population among the formed clusters 
of 186 countries associated with almost tenfold GDP increase and fivefold rise in food production.

Agricultural production in Ukraine was ranked 17th in the world. Unfortunately, other Ukrainian industries do not contribute to the overall economy the same way that agriculture does, which is why Ukraine is ranked behind 114 countries in terms of GDP. Possible improvements of such standing were clarified by comparative profiles of the top countries within and beyond the EU. They illuminated avenues of urbanization, employment in agriculture and its share in GDP, showed advantages in crop farming, exhibited prospects in animal husbandry and food security. The plausible patterns on developing agricultural sustainability and fortifying food security in Ukraine could be delivered from competitive Lithuania and prosperous Canada within and beyond the EU. They encourage rising Ukrainian food production by $17.1 \%$ and $25.4 \%$. Such progress is an imperative to meet challenges of providing the secure and sustainable feeding of the urban world now and later on.

\section{References}

Alfieri, F. (2016). Politics, economics, and demographics of food sustainability and security. Reference Module of Elsevier Inc. in Food Science. doi: 10.1016/B978-0-08-1005965.03435-1.

Arouri, M., Youssef, A. B., Nguyen-Viet, C., \& Soucat, A. (2014). Effects of urbanization on economic growth and human capital formation in Africa. Program on the global demography of aging at Harvard University: Working Paper Series, 119, 1-22. Retrieved March 11, 2020, from https://halshs.archives-ouvertes.fr/halshs-01068271/document

Babenko, V., Pasmor, M., Pankova, J., \& Sidorov, M. (2017). The place and perspectives of Ukraine in international integration space. Problems and Perspectives in Management, 15(1), 80-92. doi: 10.21511/ppm.15(1).2017.08.

Chen, A., Liu, G. G., \& Zhang, K. H. (2018). Urbanization and Social Welfare in China. London: Routledge.

Czyzewski, A., \& Smedzik-Ambrozy, K. (2015). Specialization and diversification of agricultural production in the light of sustainable development. Journal of International Studies, 8(2), 63-73. doi: 10.14254/2071-8330.2015/8-2/6.

Doss, C., Meinzen-Dick, R., Quisumbing, A., \& Theis, S. (2018). Women in agriculture: Four myths. Global Food Security, 16, 69-74. doi: 10.1016/ j.gfs.2017.10.001.

FAO (2020). Sustainable development goals. Food and agriculture data. Economic and social development department, UN Statistics. Retrieved March 15, 2020, from http://www.fao.org/home/en/

Gardner, B. (2013). Global food futures: Feeding the world in 2050. London: Bloomsbury Academic.

Godfray, H. C. J., \& Garnett, T. (2014). Food security and sustainable intensification. Philosophical Transactions of the Royal Society: Biological Sciences, 369(20120273). doi: 10.1098/rstb.2012.0273.

Grafton, R. Q., Daugbjerg, C., \& Qureshi, M. E. (2015). Towards food security by 2050. Food Security, 7(2), 179-183. doi: 10.1007/s12571-015-0445-x.

Greene, W. H. (2007). Econometric Analysis. Upper Saddle River, New Jersey: Pearson Prentice Hall.

Headey, D., \& Ecker, O. (2013). Rethinking the measurement of food security: from first principles to best practice. Food Security, 5(3), 327-343. doi: 10.1007/s12571-013-02530. 
Karamushka, O., Moroz, S., \& Vasylieva, N. (2018). Information component of innovative support for agricultural enterprises capital. Baltic Journal of Economic Studies, 4(4), 145150. doi: 10.30525/2256-0742/2018-4-4-145-150.

Katan, L., Dobrovolska, O., \& Espejo, J. M. R. (2018). Economic growth and environmental health: a dual interaction. Problems and Perspectives in Management, 16(3), 219-228. doi: $10.21511 /$ ppm.16(3).2018.18.

Kaufman, L., \& Rousseeuw, P. J. (2005). Finding Groups in Data: An Introduction Cluster Analysis. Hoboken, New Jersey: Wiley-Interscience.

Keyfitz, N., \& Caswell, H. (2010). Applied Mathematical Demography. New York, New York: Springer.

Khalatur, S., Pavlova, G., \& Zhylenko, K. (2018). The role of some indicators of financial security in Ukraine in the context of transnationalization and national interests. Investment Management and Financial Innovations, 15(3), 237-248. doi:10.21511/imfi.15(3).2018.20.

Khan, A., Khan, S., Jan, A. A., \& Khan, M. (2017). Health complication caused by protein deficiency. Journal of Food Science and Nutrition, 1(1), 1-2. Retrieved March 12, 2020, from http://www.alliedacademies.org/articles/health-complication-caused-by-proteindeficiency-8550.html

Knorr, D., Kho, C. S. H., \& Augustin, M. A. (2018). Food for an urban planet: challenges and research opportunities. Frontiers in Nutrition, 4(73). doi: 10.3389/fnut.2017. 00073

Kolesnyk, T., Samborska, O., Talavyria, M., \& Nikolenko, L. (2018). Ensuring the sustainable development of the Ukrainian agrarian sector in conditions of globalization. Problems and Perspectives in Management, 16(3), 245-258. doi:10.21511/ppm.16(3).2018.20.

Koroteyev, M., Korman, I., Manziy, O., Semenda, O., \& Semenda, O. (2017). Prospects for the market turnover of agricultural land in Ukraine. Problems and Perspectives in Management, 15(2-2), 344-354. doi: 10.21511/ppm.15(2-2).2017.04.

Kundu, A. (2011). Trends and processes of urbanization in India. Urbanization and Emerging Population Issues - 6, Human Settlements Group, IIED, Population and Development Branch, UNFPA. Retrieved March 10, 2020, from http://pubs.iied.org/10597IIED.html

McKenzie, F. C., \& Williams, J. (2015). Sustainable food production: constraints, challenges and choices by 2050. Food Security, 7(2), 221-233. doi: 10.1007/s12571-015-0441-1.

Meyers, W. H. and Kalaitzandonakes, N. (2015). World Population, Food Growth, and Food Security Challenges. Food Security in an Uncertain World: Frontiers of Economics and Globalization, 15, 161-177.

Mikalauskiene, A., Narutaviciute-Cikanauske, R., Sarkiunaite, I., Streimikiene, D., \& Zlateva, R. (2018). Social aspect of sustainable development: issues of poverty and food shortage. Montenegrin Journal of Economics, 14(2), 59-78. doi: 10.14254/1800-5845/2018.14-2.4.

Mitchell, N. H. (2011). Mathematical applications in agriculture. Boston, Massachusetts: Cengage Learning.

Satterthwaite, D., McGranahan, G., \& Tacoli, C. (2010). Urbanization and its implications for food and farming. Philosophical Transactions of the Royal Society: Biological Sciences, 365(1554), 2809-2820. doi: 10.1098/rstb.2010.0136.

Seto, K. C., \& Ramankutty, N. (2016). Hidden linkages between urbanization and food systems. Science, 352(6288), 943-945. doi: 10.1126/science.aaf7439.

Skrypnyk, A., Tkachuk, V., Andruschenko, V., \& Bukin, E. (2018). Sustainable development facets: farmland and market demand estimation. Journal of Security and Sustainability Issues, 7(3), 513-525. doi: 10.9770/jssi.2018.7.3(11).

Stage, Jes., Stage J., \& McGranahan, G. (2009). Is urbanization contributing to higher food prices? Urbanization and Emerging Population Issues - 1, Human Settlements Group, 
IIED, Population and Development Branch, UNFPA. Retrieved March 13, 2020, from http://www.iied.org/pubs/display.php?o=10573IIED

State Statistics Service of Ukraine. (2020). Agriculture in Ukraine. Statistics. Retrieved February 29, 2020, from http://www.ukrstat.gov.ua

Studenmund, A. H. (2016). Using econometrics: a practical guide. London: Pearson plc.

The World Bank Data. (2020). Agriculture \& rural development. Statistic Indicators. Retrieved March 19, 2020, from https://data.worldbank.org/indicator

Van Bavel, J. (2013). The world population explosion: causes, backgrounds and projections for the future. Facts, views \& vision in ObGyn, 5(4), 281-291.

Vasylieva, N. (2019). Problems and prospects of food security in Ukraine. Bulgarian Journal of Agricultural Science, 25(4), 668-676.

Velychko, O., \& Velychko, L. (2017). Logistical modelling of managerial decisions in social and marketing business systems. Journal of International Studies, 10(3), 206-219. doi: $10.14254 / 2071-8330.2017 / 10-3 / 15$. 